\title{
Dvorní rada Julius Frieser (1843-1908) a identifikace minerálů z jeho sbírky ve sbírce Národního muzea v Praze
}

\author{
Court council Julius Frieser (1843-1908) and identification of minerals from his \\ collection in the collection of the National Museum in Prague
}

\section{Miroslav Radoň ${ }^{1}$ \& Dalibor Velebil ${ }^{2, *}$}

\author{
${ }^{1}$ Regionální muzeum v Teplicích, p. o., Zámecké náměstí 517/14, 41501 Teplice \\ ${ }^{2}$ Národní muzeum, Mineralogicko-petrologické oddělení, Cirkusová 1740, 19300 Praha 9; \\ dalibor.velebil@nm.cz \\ * corresponding author
}

Radoň M. \& Velebil D., 2021: Dvorní rada Julius Frieser (1843-1908) a identifikace minerálů z jeho sbírky ve sbírce Národního muzea v Praze. - Journal of the National Museum (Prague), Natural History Series 190: 73-86.

\begin{abstract}
Abstrakt: Julius Frieser (1843-1908) byl významným sběratelem minerálů, který se zasloužil o výzkum minerálů Českého středohoří, zejména zeolitů. Osobně objevil novou lokalitu minerálu mesolitu v Bedřichově u Benešova nad Ploučnicí. Byl známý mezi profesionálními mineralogy z Prahy a Vídně, i mezi dalšími sběrateli minerálů. Byl členem litoměřického klubu sběratelů minerálů, který okolo přelomu 19. a 20. století pořádal v Litoměřicích pravidelné burzy minerálů, navštěvované slavnými geology a mineralogy. Vybudoval velkou systematickou sbírku minerálů z celého světa čítající asi čtyři tisíce položek a 350 druhů. Po jeho smrti získala sbírku, nebo její část, sběratelka Julia Schildbachová z Mariánských Lázní. Její sbírka skončila v roce 1946 v Národním muzeu v Praze. Mezi minerály od Schildbachové se aktuálně podařilo identifikovat 854 položek pocházejících původně od Friesera.
\end{abstract}

\begin{abstract}
Julius Frieser (1843-1908) was a prominent mineral collector who contributed to the research of minerals of the Bohemian Central Mountains, especially zeolites. He personally discovered a new mesolite mineral site in Bedřichov near Benešov nad Ploučnicí. He was known among professional mineralogists from Prague and Vienna, as well as among other collectors of minerals, and was a member of the Litoměřice mineral collectors' club, which organized regular mineral exchanges in Litoměřice around the turn of the $19^{\text {th }}$ and $20^{\text {th }}$ centuries, visited by famous geologists and mineralogists. He built a large systematic collection of minerals from around the world, which included about four thousand items and 350 species. After his death, the collection, or part of it, was acquired by the collector Julia Schildbach from Mariánské Lázně. Her collection was acquired by the National Museum, Prague in 1946. Among Schildbach's minerals, 854 items originally from Frieser have currently been identified.
\end{abstract}

Klíčová slova: Julius Frieser, minerály, Litoměřice, České středohoří, Národní muzeum Praha, Čechy, Česká republika

Keywords: Julius Frieser, minerals, Litoměřice (Leitmeritz), České středohoří Mts. (Böhmische Mittelgebirge), National Museum Prague, Bohemia, Czech Republic

Received: 25 May 2021 | Accepted: 8 November 2021 | Published on-line: 11 November 2021 


\section{Úvod}

Julius Frieser (1843-1908) byl významným sběratelem minerálů působícím ve druhé polovině 19. století. Byl známý jak mezi tehdejšími profesionálními mineralogy, tak mezi dalšími sběrateli minerálů. Byl jedním z prvních členů Vídeňské mineralogické společnosti a zasloužil se o výzkum minerálů Poběžovicka a Českého středohoří. Větší část života strávil v Litoměřicích, kde působil jako rada vrchního zemského soudu. Byl členem litoměřického klubu sběratelů minerálů, který pořádal každoroční mineralogické burzy. Těch se účastnili i věhlasní mineralogové a geologové (Peiter 1931). Jako zralý muž se koncem 90. let 19. století stal mentorem tehdy mladičkému Felixi Cornu (1882-1909), později významnému mineralogovi a petrografovi. Julius Frieser byl aktivním terénním sběratelem, ale minerály pořizoval i koupěmi a výměnami. Vybudoval rozsáhlou systematickou sbírku minerálů z celého světa, kterou později získala další významná sběratelka minerálů - Julia Schildbachová z Mariánských Lázní (Bohatý \& Velebil 2018). S její sbírkou přešla část Frieserovy sbírky do Národního muzea v Praze, kde se aktuálně podařilo velkou část mineralogických vzorků původem od Friesera identifikovat.

\section{Život J. Friesera}

Julius Frieser se narodil 23. záŕí 1843 v obci Čeminy (Tschemin), severně od Města Touškova (Tuschkau), asi 10 km severozápadně od Plzně, v domě č. p. 6. Pokřtěn byl jako Julius Adalbert Gerhard Frieser (Radoň 2016). Jeho otec Josef Jan Nepomuk Frieser (1811-1877) byl zaměstnán ve službách Julia hraběte z Klebelsbergu na Thumburgu jako úřední ředitel Klebelsbergova statku Libořice u Žatce, a od roku 1843 byl Josef Frieser úředním ředitelem statku Čeminy (Radoň 2016). Ještě v Libořicích se v roce 1842 oženil s Leopoldinou Rokyta (1821-1904) z Buškovic u Loun. Po synovi Juliovi se manželům Frieserovým narodily ještě dcery Josephine (1844), Ida (1846) a synové Johann (1850), Alfred (1851) a Georg (1854) (Radoň 2016).

Julius Frieser absolvoval Gymnázium v Plzni a vysokou školu (Hochschule) v Praze (Anonymus 1906a, b). Po skončení studií započal svou profesní kariéru v justici. Dne 15. prosince 1866 nastoupil jako právní praktikant u c. k. krajského soudu v Pzni. V roce 1867 byl jmenován auskultantem ${ }^{1}$ c. k. vrchního zemského soudu v Praze. Ve funkci auskultanta tehdy působil též u okresního soudu v Českém Dubu (Anonymus 1908a). V roce 1869, po uplynutí zákonné lhůty dvou let, byl jmenován soudním adjunktem u c. k. krajského soudu v Litoměřicích a stal se tak pomocným soudcovským úředníkem. Kromě německého jazyka ovládal Frieser velmi dobře i český jazyk, takže při přelíčeních porotního soudu s česky mluvícími obžalovanými působil také jako tlumočník (Anonymus 1872).

Dne 14. května 1872 se Julius Frieser v Litoměřicích oženil s Terezií Kreutzig (též Kreuzig) (1850-1931) z Vejprt. V té době bydlel Frieser v dnešní litoměřické ulici Osvobození
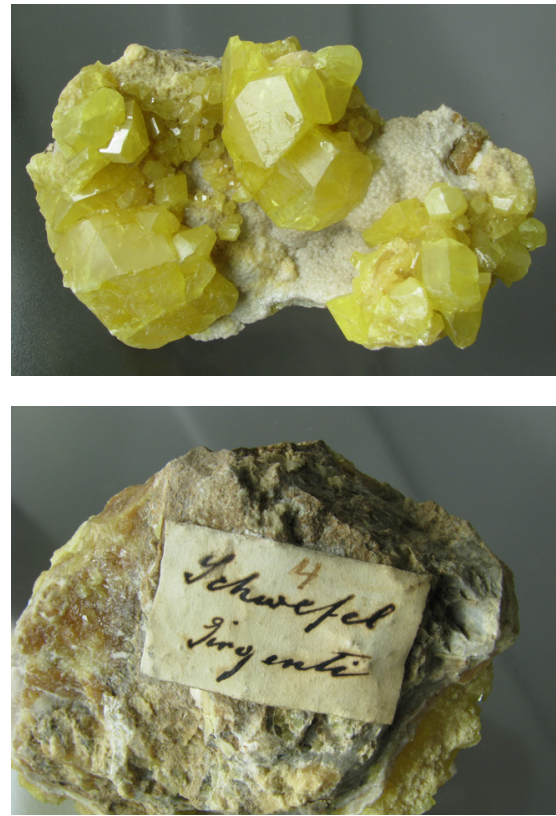

Obr. 1, 2. Síra, Agrigento, Sicílie, Itálie, $9 \times 6$ cm (Národní muzeum P1N68989, ex coll. J. Frieser no. 4). Foto: D. Velebil.

1 Auskultant byl absolvent studia práv, který se praxí u soudu připravoval ke složení soudcovské zkoušky. 
v domě č. 54/3 na tzv. Josefském předměstí, za někdejší komunální reálnou školou. $V$ následujícím roce, konkrétně 20 . záŕí 1873, se manželům Frieserovým narodila dcera Theresia. Tou dobou bydleli Frieserovi $\mathrm{v}$ domě č. 169/38 na Mírovém náměstí (Ringplatz), vedle staré litoměřické radnice. $V$ tomto domě se jim 15. května 1876 narodil syn Hermann. Od roku 1877 bydleli Frieserovi v domě č. 3 s domovním znamením „U Božího oka“v Jezuitské ulici (Ressel 1877).

V Litoměřicích se Julius Frieser zapojil do spolkového života. Byl členem Spořitelního a úvěrního spolku pro Litoměřice a okolí (Spar- und Vorschussverein für Leitmeritz und Umgebung), založeného $\mathrm{v}$ roce 1872. Opakovaně byl volen jedním $\mathrm{z}$ účetních revizorů hospodaření tohoto spolku (Anonymus 1875a, 1876a, b). Byl rovněž členem Vysazovacího a okrašlovacího spolku (Anpflanzungs- und Verschönerungsverein) založeného roku 1869. Cílem tohoto spolku bylo zlepšování městského prostředí vysazováním zeleně (Blumentritt 1912).

Nejpozději od roku 1874 byl Julius Frieser členem Zábavního a vzdělávacího

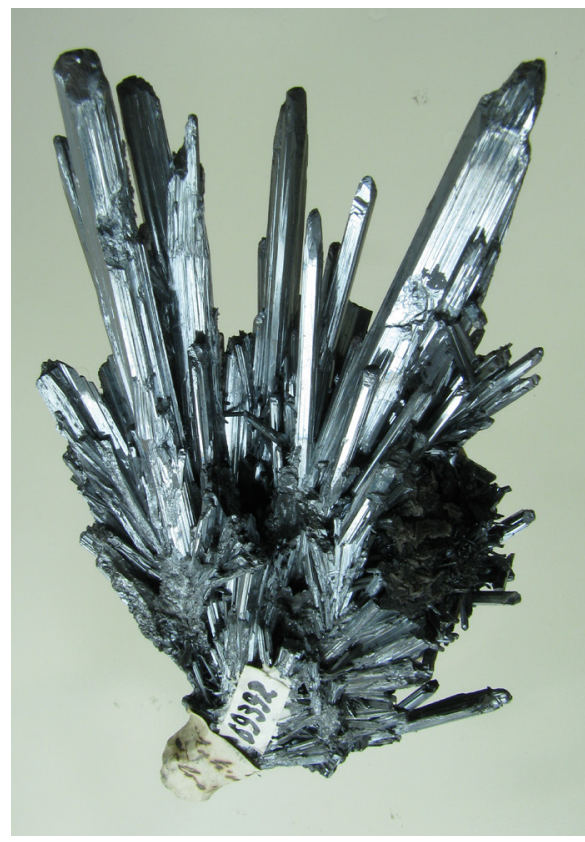

Obr. 3. Antimonit, Baia Sprie, Rumunsko, $8 \times 5$ cm (Národní muzeum P1N69392, ex coll. J. Frieser no. 230). Foto: D. Velebil. spolku Schiller (Fortbildungsverein Schiller), založeného v roce 1865. Tento spolek byl obdobou či jakousi protiváhou české Besedy, založené již roku 1862. Spolek Schiller měl podněcovat „Všeobecné vzdělávání a podporovat společenskou družnost“. Během pravidelných večerních setkání tohoto spolku vedl Frieser, stejně jako další členové spolku, přednášky na rozmanitá témata. Tak například 28. listopadu a 12. prosince 1874 měl na pokračování přednášku o expedicích na severní pól. Úspěšnou přednášku doprovodil ukázkami map, včetně mapy nově objevené Země Františka Josefa (Anonymus 1874a, b, c). Počátkem roku 1875 byl Frieser zvolen pro tento rok předsedou spolku Schiller (Anonymus 1875b). V roce 1875 měl Frieser přednášku Síla tónů (Anonymus 1875c), v roce 1878 přednášky o astronomovi Secchim, o meteorologii a o bouřkách, v roce 1879 o meteorech (Anonymus 1878). Frieser byl také členem výboru litoměřického spolku „Ledový klub“ (Eisclub), založeného v roce 1876. Tento spolek se věnoval „ledovému sportu a společenské zábavě“ (Ressel 1877).

V roce 1880 pracoval Julius Frieser jako soudní adjunkt litoměřického krajského soudu, ve stejné funkci působil také při okresním soudu v Úštěku (Anonymus 1908a). V roce 1881 byl po dvanácti letech ve funkci soudního adjunkta konečně jmenován soudcem, a to při okresním soudu v Poběžovicích (Ronsperg) na Domažlicku (Anonymus 1881a, b). Rodina se tedy musela stěhovat. I v Poběžovicích se Frieser aktivně zapojil do místní spolkové činnosti. V neděli 9. července 1882 se konalo ustavující shromáždění místní organizace Německého školského spolku (Deutscher Schulverein), během kterého byl Julius Frieser zvolen předsedou spolku (Anonymus 1882). Jako okresní souce v Poběžovicích působil Frieser necelé čtyři roky. V roce 1885 zažádal o přeložení do svého rodného kraje, k okresnímu soudu ve Městě Touškově, a jeho žádosti bylo vyhověno (Anonymus 1885a-c).

Po čtyřech letech v Poběžovicích a dalších osmi letech ve Městě Touškově se roku 1893 rodina přestěhovala zpět do Litoměřic. $\mathrm{V}$ tomto roce byl totiž Julius Frieser jmenován c. k. radou zemského soudu a přísedícím důchodkového soudu v Litoměřicích (Anonymus 1893a-c, 


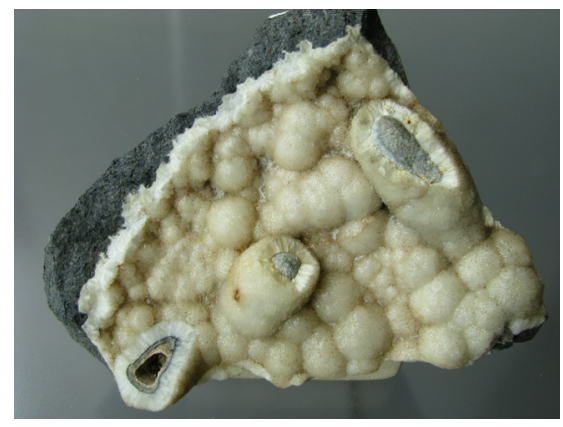

Obr. 4. Thomsonit, Křížová hora, ssv. od Litoměřic, Čechy, velikost $8,5 \times 8,5 \mathrm{~cm}$ (Národní muzeum P1N70629, ex coll. J. Frieser no. 2055). Foto: D. Velebil.
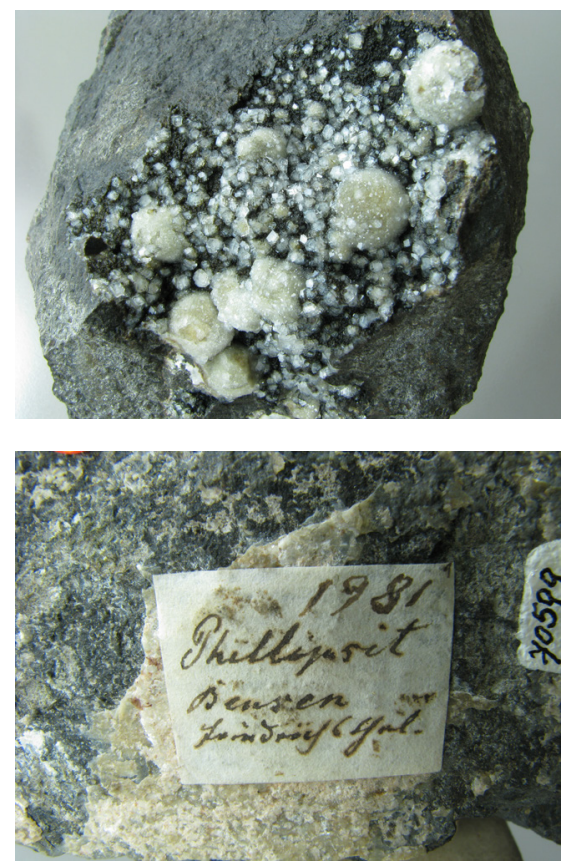

Obr. 5, 6. Phillipsit, Benešov nad Ploučnicí, Čechy, $6 \times 4$ cm velká drúza krystalů (Národní muzeum P1N70599, ex coll. J. Frieser no. 1981). Foto: D. Velebil. 1906a, b). Frieser byl pak pravidelně volen také jedním ze zástupců porotního soudu při litoměřickém krajském soudu (Anonymus 1894, 1895).

V Litoměřicích bydleli Frieserovi jinde než během jejich pobytu v letech 1872-1881, a to na litoměřickém předměstí $v$ domě na ulici Kaiser Franz Josefs- Strasse (Masarykova), opatřeného číslem popisným 470a,b a orientačními čísly 55 a 57 tehdejšího číslování (Seifert 1903). Dnes nese tento dům na rohu ulic Plešivecká a Masarykova číslo 470/2. Julius Frieser navázal na své členství ve všech výše uvedených spolcích, které i po dvanácti letech stále ještě existovaly. Na sklonku života se stal ještě předsedou litoměřického Kasina státních úředníků (Staatsbeamtenkasino). Zastával také čestné místo člena ředitelství litoměřické městské spořitelny, kde byl považován za vynikajícího spolupracovníka, jehož blahodárné působení přispělo $\mathrm{k}$ prosperitě firmy (Anonymus 1908d). V roce 1895 se provdala Frieserova dcera Theresia za Karla Johanna Wirnitzera (1867-1926), záložního rezervistu c. k. českého zeměbraneckého pěšího pluku č. 6 v Chebu a c. k. adjunkta berního úřadu ve Frýdlantu č. p. 711. Syn Hermann Frieser pracoval v té době jako technik v Litoměřicích. V roce 1899 absolvoval techniku v Praze a stal se inženýrem. Oženil se s Helenou Starou, dcerou ředitele plzeňské spořitelny Johanna Starého (Radoň 2016).

V Litoměřicích se Julius Frieser dočkal dalšího kariérního postupu. Od roku 1898 byl přednostou litoměřického okresního soudu (Anonymus 1899, 1900), v roce 1902 byl jmenován c. k. radou vrchního zemského soudu (Anonymus 1906a, b, 1908a) a v roce 1905 byl rozhodnutím císaře Františka Josefa I. jmenován viceprezidentem krajského soudu v Litoměřicích (Anonymus 1905, 1908a).

V sobotu 15. prosince 1906 oslavil Julius Frieser v Litoměřicích své 40leté služební jubileum (Anonymus 1906a-d). V té době byl vedoucím trestního soudního oddělení krajského soudu. Po dobu svého více než 25letého působení v Litoměřicích se díky svému smyslu pro spravedlnost a smírrlivé povaze těšil sympatiím

obyvatel Litoměřic i soudních úředníků. Služební jubileum bylo oslaveno ve vyzdobeném jednacím sále budovy trestního soudu. Slavnostní řeč k jubilantovi pronesl prezident krajského soudu, dvorní rada Franz Jedlitschka, který Frieserovi předal i pamětní medaili (Radoň 2016).

V květnu 1907 absolvoval Julius Frieser s manželkou léčebný pobyt v Karlových Varech (předtím pobýval v Karlových Varech již roku 1879) a v září 1907, ve svých 64 letech, zažádal 


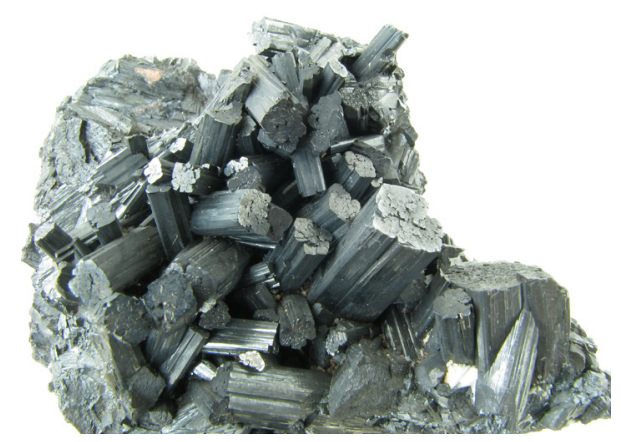

Obr. 7. Manganit, Ilfeld, Německo, drúza velikosti $7 \times 3 \mathrm{~cm}$ (Národní muzeum P1N69641, ex coll. J. Frieser no. 2269). Foto: D. Velebil.

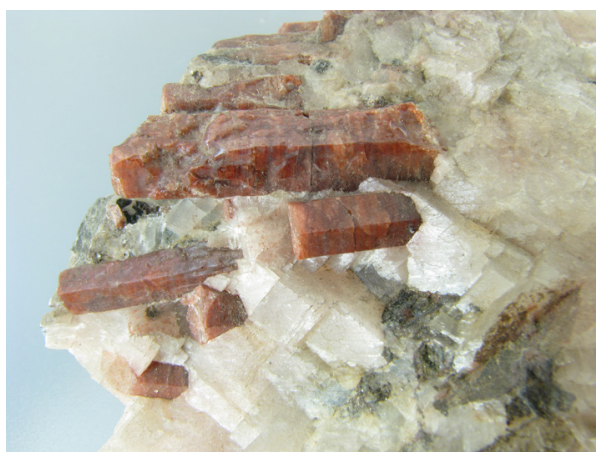

Obr. 8. Apatit, Kanada, krystaly velikosti až $3 \mathrm{~cm}$ (Národní muzeum P1N71509, ex coll. J. Frieser no. 1309). Foto: D. Velebil.

o přeložení do penze. Jeho žádosti bylo císařem Františkem Josefem I. vyhověno a při té příležitosti mu byl propůjčen titul dvorního rady (Anonymus 1907a-c; Radoň 1916).

Odpočinku na penzi si ale Julius Frieser př́liš neužil, byl totiž vážně nemocný. Viceprezident krajského soudu v Litoměřicích, dvorní rada Julius Frieser, zemřel v sobotu 27. června 1908 ve 22:30 hodin ve věku 67 let ve všeobecné nemocnici v Plzni, kam byl krátce před smrtí převezen z Města Touškova, kde chtěl již jako penzista v poklidu strávit letní dny (Anonymus 1908a-e). Př́ćinou smrti byla rakovina tlustého střeva. Pohřben byl ve Městě Touškově za účasti uniformovaných členů několika spolků, c. k. rady vrchního zemského soudu Maxe Zeidlera, c. k. rady zemského soudu Emila Sandera a dalších významných osobností. V nekrologu uveřejněném v litoměřických novinách vyzdvihli Frieserovu laskavost a dobrosrdečnost, kterou projevoval jak v soukromém životě, tak i během své profese. Vdova Theresia Frieser žila až do své smrti v roce 1931 v Litoměřicích v domě č. 618/18 v Turgeněvově ulici (Dr. Fleischergasse) (Radoň 1916).

\section{Mineralogické aktivity J. Friesera}

Julius Frieser se věnoval obětavě svému povolání, kromě toho si ovšem našel čas i na spolkovou činnost a na své záliby, kterými byla hudba, umění a př́rodověda v širokém slova smyslu a z ní především mineralogie. Během svého života vybudoval rozsáhlou sbírku minerálů. Jako aktivní a vášnivý sběratel minerálů byl znám nejen v Litoměřicích, ale i v širších mineralogických kruzích. Mineralogické vzorky z jeho sběrů využili k výzkumům významní mineralogové v Praze i ve Vídni (Radoň 1916).

Frieser postupně prozkoumal všechny tehdy známé mineralogické lokality Českého středohoří, a to v době, kdy díky do značné míry ruční těžbě vydaly tamní kamenolomy nejvýraznější vzorky minerálů, které dnes obdivujeme v muzejních i soukromých sbírkách. Frieserovi se také dařilo vyhledávat lokality nové. Např́iklad někdy po roce 1893 objevil výskyt minerálu mesolitu v kamenolomu u osady Bedřichov (Friedrichsthal) v údolí řeky Ploučnice mezi Františkovem a Benešovem nad Ploučnicí. V sousedství kamenolomu stál a dodnes stojí areál budov někdejší přádelny vedené Frieserovým bratrem Alfredem. Je pravděpodobné, že J. Frieser učinil objev během návštěvy svého bratra (Radoň 2016). Nový výskyt mesolitu popsal v roce 1909 mineralog Rudolf Görgey (1886-1915). Z jeho textu vyplývá, jakým způsobem putovaly vzorky určené k výzkumu, a jsou v něm naznačeny obtíže s determinací zeolitových minerálů (s nimiž se potýkají i dnešní mineralogové). Görgey uvedl: „Mezi minerály z Bedřichova, které mi ke zpracování přenechal můj př́tel Felix Cornu, jsem ve srůstu s natrolitem objevil jeden zeolit, který jsem podle jeho optických vlastností nemohl ztotožnit s žádným známým zeolitem. Kvůli nedostatku materiálu k analýzám jsem tehdy výzkum odložil. Při ná- 

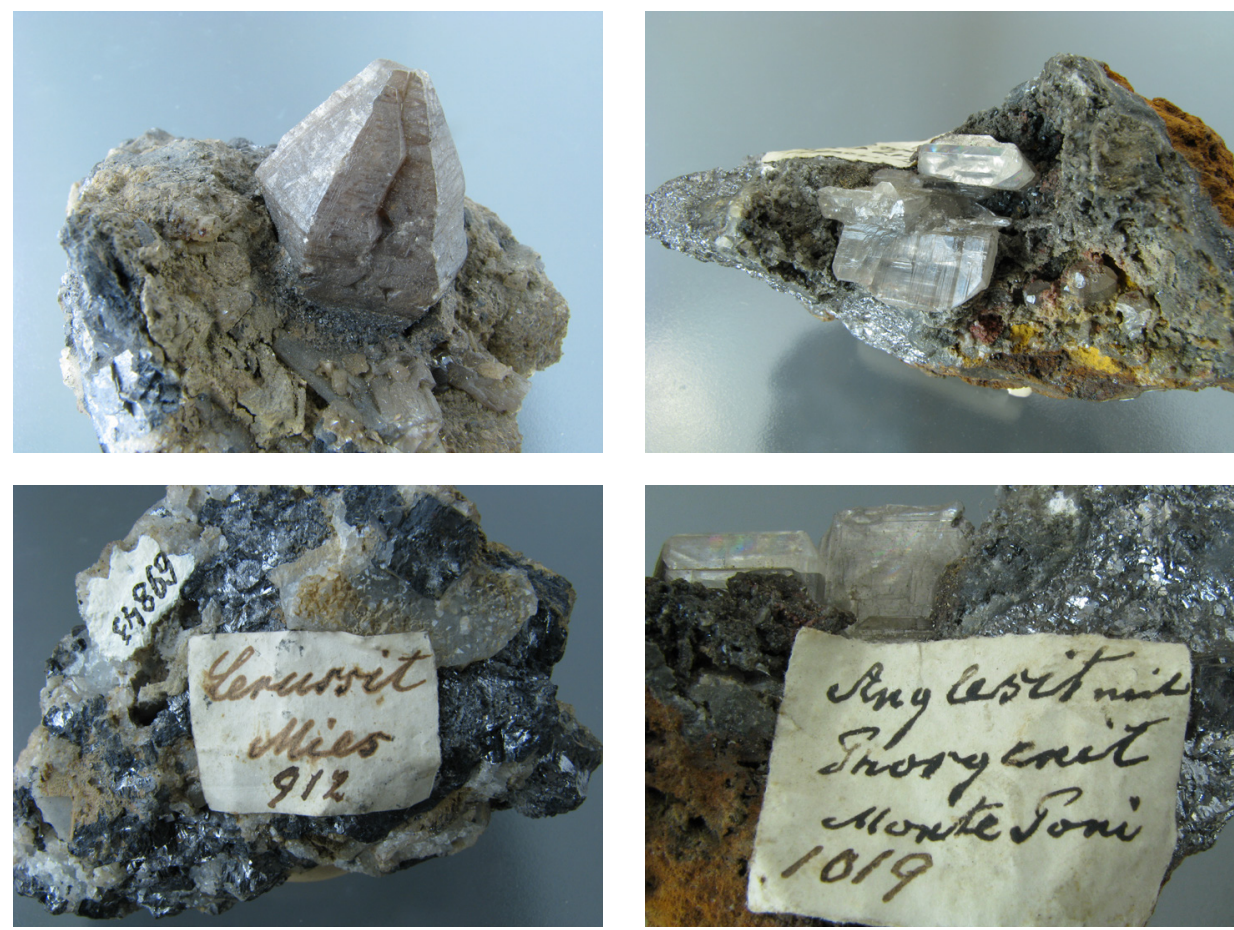

Obr. 9, 10. Cerusit, Stříbro, Čechy, krystal velikosti 2,5 cm (Národní muzeum P1 N69843, ex coll. J. Frieser no. 912). Foto: D. Velebil.

Obr. 11, 12. Anglesit, Monte Poni, Sardinie, Itálie, krystal velkosti 1,5 cm v galenitu (Národní muzeum P1N71467, ex coll. J. Frieser no. 1019). Foto: D. Velebil.

vštěvě mineralogického muzea v Kodani v Dánsku jsem viděl pěkné vzorky mezolitu z Faerských ostrovů a zeptal jsem se pana docenta Bøggilda, který nás provázel, jak odlišuje mezolit od natrolitu a skolecitu. Když mi optické vlastnosti mezolitu popsal, ihned jsem si vzpomněl na zeolit z Bedřichova. Skutečně jsem pak mohl pod mikroskopem zjistit identitu obou těchto zeolitü, nebot' mi pan docent Ove Balthasar Bøggild nezištně poskytl pěkný srovnávací materiál. Rovněž $z$ naleziště v Bedřichově jsem také dostal ještě další vzorky od pana dvorního rady J. Friesera z Litoměřic, od něhož pocházely i první uvedené vzorky. Těmto dvěma pánům jsem zavázán velkým poděkováním za jejich mimořádnou laskavost. Pan dvorní rada Frieser, jenž se velmi zasloužil o prozkoumání zeolitů Českého středohoří, mezitím bohužel zemřel." (Görgey 1909).

Frieserovo prvenství nálezu mesolitu v Bedřichově později potvrdil také významný geolog a petrolog Josef Emanuel Hibsch (1852-1940), který napsal: „Vycházejíc z výskytu mezolitu v údolí Ploučnice vedle prádelny v Bedřichově, který jako první objevil pan J. Frieser, rozšíril Görgey své výzkumy také na další výskyty v Českém středohoří a mimo něj." (Hibsch 1934). Mesolit tvořil v kamenolomu v Bedřichově 3 až 7 mm dlouhé jehlicovité krystaly narostlé na phillipsitu v dutinách čediče. Jehličky mezolitu přitom nebyly nikdy homogenní, byly to orientované srůsty natrolitu a mezolitu do jedné zdánlivě jednotné jehlice. Hrany prismat natrolitu a mezolitu byly přitom vzájemně paralelní (Görgey 1909, Hibsch 1934). Kamenolom v Bedřichově, v němž byly učiněny nálezy mesolitu, lze i dnes navštívit, nachází se nad železniční tratí naproti budovám bývalé přádelny. Je ale, bohužel, zcela zašlý a zarostlý (Radoň 2016).

V roce 1896 napsal lékař a sběratel minerálů Adalbert Wraný (1836-1902) o Frieserovi, že „má všeobecnou mineralogickou sbírku, a že mineralogicky prozkoumal okolí Poběžovic, kde 
ostatně po dobu necelých čtyř let žil a pracoval, a uvedl tamní minerály ve známost" (Wraný 1896; o Wraném in: Bohatý \& Velebil 2019). Terénním mineralogickým výzkumům se tedy věnoval i během svého čtyřletého pobytu v Poběžovicích, odkud pocházejí zejména ukázky berylu, almandinu a muskovitu z pegmatitů.

Ve stejném roce 1896 došlo k osudovému setkání Julia Friesera s mladičkým, teprve třináctiletým Felixem Cornu (1882-1909), později slavným, byt' předčasně zesnulým profesionálním mineralogem, autorem 85 vědeckých prací. $\mathrm{V}$ tomto roce se rodina Felixe Cornu, respektive Felix, jeho bratr Adolf a jejich matka Marie přestěhovali z Prahy do Litoměřic, kde po smrti Felixova tříletého bratra Julia hledali příznivější podmínky pro život. Otec rodiny Julius Cornu, vysokoškolský profesor románské filologie na pražské německé univerzitě, pobýval nadále po většinu roku v Praze. V Litoměřicích bydlela rodina Cornuových v domě č. 679 na ulici Kaiser Franz Josefs-Strasse (dnes Masarykova) a byli blízkými sousedy Frieserových. V letech 1898 až 1901 bydleli Cornuovi dokonce ve stejném domě jako Frieserovi, a sice v domě s dnešním číslem 470/2 na rohu ulic Plešivecká a Masarykova (tehdy Kaiser Franz Josefs-Strasse č. 55).

Po přestěhování nastoupil Felix Cornu do třetí třídy litoměřického Státního gymnázia, kde se stal oblíbeným žákem zdejšího profesora Gustava Nowaka. Měl výrazný zájem o př́írodopis a zejména o minerály. Brzy se seznámil s Juliem Frieserem, který se mu stal i přes téměř 40letý věkový rozdíl v jejich společném zájmu partnerem a oba společně vyráželi za minerály do okolí Litoměřic. Gustav Nowak na to později vzpomínal takto (Nowak 1923): „V září 1896 nastoupil do třetí tř́dy litoměřického gymnázia nový žák, který přišel ze Státního gymnázia v Praze ve Štěpánské ulici (Stephansgasse), kde absolvoval primu a sekundu. Jeho jméno bylo Felix Cornu. (...) Nový žák, milý statný chlapec, na sebe brzy upozornil svou veselou horlivostí a svými vědomostmi. Zcela zvláštní zaujetí projevil pro př́rodopis, zejména pak pro mineralogii. V každé vyučovací pauze stál před vitrínami a prohlížel si vystavené předměty, a já jsem mu nemohl udělat ničím větší radost, než když jsem mu povolil prohlídku př́rodovědného kabinetu. Nebyla to zvědavost, ale touha po poznání, co tohoto třináctiletého chlapce stále více a více přitahovalo $k$ minerálům. Zatímco se jeho školní kamarádi proháněli po hřištích, anebo se věnovali jiné zábavě, pátral on většinou se známým mineralogem radou vrchního zemského soudu Juliem Frieserem, sousedem a př́telem jeho rodičů, anebo s obchodníkem s minerály Fritzem Leitenbergerem, v okolí Litoměřic po kamenech, které pak použil zčásti k doplnění své sbírky a zčásti $k$ výměnám. Zpočátku to byli většinou spolužáci a menší sběratelé, s nimiž si kameny vyměňoval, brzy se však díky prostředkům, které mu poskytla matka, dostal do trvalého spojení s velkými sběratelskými subjekty, zvláště s královskou saskou mineralogickou obchodní základnou ve Freibergu. Jako kvartán založil s několika k tomu získanými spolužáky klub Gea, který později pojmenoval jako Litoměřické sdružení pro výměnu minerálů (Leitmeritzer Mineralien-Tauschverband). (...) Svým srdečným sympatickým vystupováním, svou otevřenou upř́mností a mnohostrannými znalostmi, které si osvojil, si získal nejvřelejší blahovůli a laskavost profesorů J. E. Hibsche, Antona Pelikana, Alexandera Weinberga, Franze Wolfa von Wolfinau, ředitele polnohospodářské školy Antona J. Kollara, odborného učitele měšt'anské školy W. Martinovského z Mimoně, rrídícího učitele obecné školy Wenzela Peitera z Velemína, a konečně prece Felixova nezapomenutelného otcovského př́tele dvorního rady Julia Friesera. (...)“

Také Cornuho matka Marie vzpomínala na přátelství svého syna s Juliem Frieserem: „(...) Kromě toho jsme získali vřelého přítele plného porozumění v osobě pozdějšího soudního prezidenta dvorního rady Julia Friesera. Tento zkušený, vyzrálý muž a třináctiletý chlapec se stali brzy nerozlučnou dvojicí. Frieser sám říkával - denní kontakt s Felixem je pro mě svěže klokotajícím pramenem po často nudné práci v zaměstnání. Srdečně se těším na jeho příchod! - Jako pro vášnivého mineraloga pro něho Felix horoval. Pěkné okolí v jeho rozmanitosti, nádherné plavby po Labi a množství nalezišt' minerálů, to vše poznával v inspirující společnosti svého otcovského prrítele. Hovořili, smáli se a debatovali o všem možném." (Cornu 1923).

Univerzitní profesor Friedrich Becke a Cornuho učitel na vysoké škole vzpomněl na vztah Friesera s Cornuem, když napsal: „Felix Cornu, podpořen schopným učitelem, profeso- 


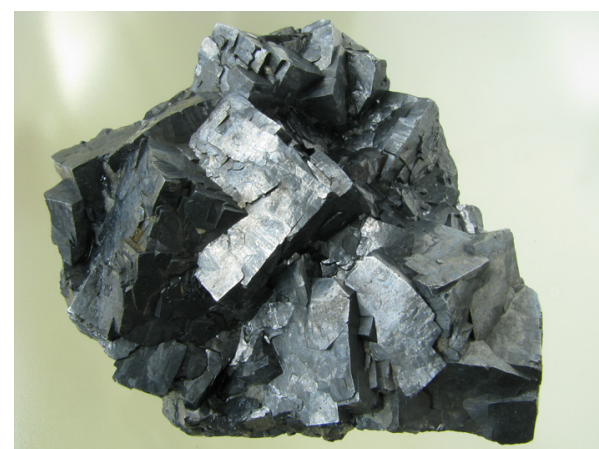

Obr. 13. Galenit, Stříbro, Čechy, velikost $8 \times 7 \mathrm{~cm}$ (Národní muzeum P1N69198, ex coll. J. Frieser no. 136). Foto: D. Velebil.

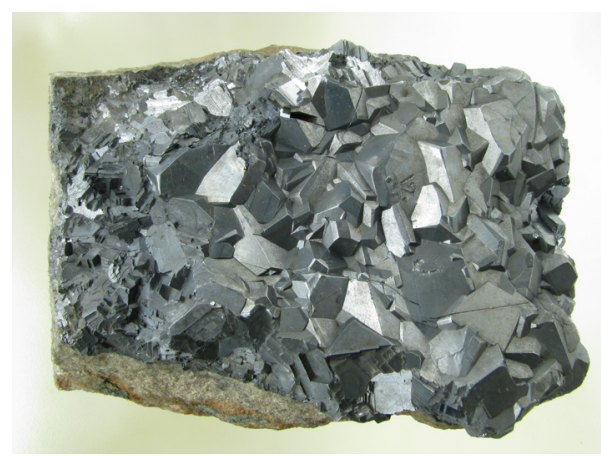

Obr. 14. Galenit, Př́ibram, Čechy, velikost 11 $\times 8 \mathrm{~cm}$ (Národní muzeum P1N69196, ex coll. J. Frieser no. 130). Foto: D. Velebil.

rem Nowakem na gymnáziu v Litoměřicích, kde strávil chlapecká léta, a povzbuzen účastnými přáteli, jako byli profesor vyšší reálné školy Weinberg a coby sběratel v širších kruzích známý rada vrchního zemského soudu Frieser v Litoměřicích, získal již jako mladý muž obdivuhodnou znalost minerálů a zbystřil své přirozené pozorovatelské nadání." (Becke 1909).

Ve svých mineralogických aktivitách Julius Frieser samozřejmě pokračoval i po odchodu Felixe Cornu na studia do Vídně. V roce 1901 byla založena Vídeňská mineralogická společnost (Wiener Mineralogische Gesellschaft) a Frieser se stal velmi záhy jejím členem (Radoň 1916).

Okolo přelomu 19. a 20. století byly Litoměřice, jak se zdá, jakýmsi centrem sběratelství minerálů. V tomto městě působil významný obchodník s minerály Fritz Leitenberger (18571910), který byl bezpochyby nejdůležitějším Frieserovým dodavatelem především zahraničních minerálů (Bohatý, Velebil 2018). Působil zde také mladý sběratel Cornu a v Litoměřicích se pořádaly pravidelné mineralogické burzy, na které se sjížděli profesionální mineralogové a sběratelé minerálů i ze vzdálenějších končin (Peiter 1931).

V roce 1902 poslal Frieser do sbírek Vídeňské mineralogické společnosti zásilku pěkných vzorků natrolitu ze známé lokality na Břidličném vrchu u obce Dolní Zálezly (Anonymus 1902). Ve stejném roce přispěl do sbírek téže společnosti ještě zásilkou minerálů nově nalezených při stavbě železniční trati u Horního Slavkova. Jednalo se o vzorky minerálu autunitu v podobě malých tabulkovitých krystalů na dalších sekundárních minerálech, které se zde vyskytly spolu s uraninitem (Anonymus 1903). Vídeňská mineralogická společnost pořádala v budově mineralogicko-petrografického ústavu vídeňské univerzity pravidelné komorní výstavy minerálů. $\mathrm{V}$ roce 1906 se Frieser podílel na realizaci jedné z těchto výstavek věnované minerálu kasiteritu. Na výstavku zapůjčil své vzorky kasiteritu z lokalit Ehrenfriedersdorf, Krupka, Cínovec a Horní Slavkov (Anonymus 1906e).

Felix Cornu ve svých odborných pracích často děkoval různým osobám za vzorky minerálů poskytnuté $\mathrm{k}$ mineralogickému výzkumu. Několikrát přitom zmínil i Julia Friesera. Např́klad v roce 1903 napsal ve své práci o zeolitech z Českého středohoří: „Závěrem bych chtěl ještě uvést, že za některé vzorky z mého materiálu vděčím laskavosti pánů profesora Al. Weinberga a rady vrchního zemského soudu Friesera z Litoměric." (Cornu 1903). Frieserovi děkuje i v pojednání o fylosilikátech (Cornu 1906) či o minerálech z Mariánské hory v Ústí nad Labem (Cornu 1911). Ještě řadu let po Frieserově smrti děkovali autoři různých odborných článků za mineralogické vzorky, které poskytl vědeckým institucícm k výzkumu (Radoň 2016).

Zásluhy Julia Friesera o poznání mineralů Českého středohoří ocenil i největší znalec geologické stavby tohoto území J. E. Hibsch. Hibsch (1934) v úvodu své obsáhlé práce o minerá- 
lech Českého středohoří uvedl: „zásadní podporu našly výzkumné práce ve sběratelské činnosti J. Friesera a F. Leitenbergera v Litoměřicích atd." V pozdějších dodatcích k této práci Hibsch zmínil, že „Vídeňské muzeum v minulosti získalo jeden pěkný vzorek zeofylitu z lokality Velké Březno od pana rady zemského soudu J. Friesera z Litoměřic, který narozdíl od materiálu od A. Pelikana vykazuje měritelné krystaly." (Hibsch 1937).

\section{Frieserova mineralogická sbírka}

Julius Frieser vybudoval rozsáhlou mineralogickou sbírku. Až do dnešních dob ovšem o ní nebylo známo nic bližšího. V roce 1908 se o ní zmínil neznámý autor Frieserova nekrologu v litoměřických novinách. Podle něj sbírka zasluhovala důstojné využití a měla by sloužit veřejnosti k výuce (Anonymus 1908d).

Sbírka byla dlouho považována za ztracenou. Nasvědčovala tomu i zpráva řídícího učitele Wenzela Peitera z Velemína z roku 1931 o minerálech litoměřického okresu, z níž se mimo jiné dozvídáme zajímavé údaje o činnosti mineralogické komunity v Litoměřicích: „Město Litoměřice bylo kdysi bohaté na kameny, a sice v době kdy ještě v Leitenbergerově vinárně konal své schůze, koncem minulého a začátkem tohoto století, klub sběratelu minerálů, mezi jehož členy a horlivými sběrateli byly také ženy, a kdy sem na návštěvu burzy minerálů přicházeli nejslavnější mineralogové a geologové. Svým rozsáhlým výměnným obchodem a obzvláště svým spojením se zahraničními velkoobchodníky mohl Leitenberger opatřit každý minerál či horninu, pokud nebyly na skladě. Bohužel město nenašlo pochopení pro to, aby pro městské muzeum zajistilo neobyčejně cenné sbírky Cornuho, rady zemského soudu Friesera, Leitenbergera a jiných členů klubu. Tyto sbírky byly všemi větry rozprášeny a tak se ztratily obzvláště ty nejhezčí dokladové vzorky minerálů okresu. Pokud si nějaký takový vzorek pro svůj ústav nezajistil ani již zemřelý ředitel zemědělské školy Kolar, či profesor a nynější inspektor ovocnářství Schmied, bude možné, že bude výskyt některého či jiného minerálu v okrese zpochybněn." (Peiter 1931).

Až v roce 2015, během bádání o osobnosti sběratelky Julie Schildbachové (1880-1962) z Mariánských Lázní (Bohatý \&Velebil 2018), bylo analýzou katalogu její mineralogické sbírky zjištěno, že Frieserovu sbírku minerálů získala, bud' celou nebo alespoň její velkou část, právě ona. Sbírku odkoupila, nejspíše od vdovy Theresie Frieserové, až po Frieserově smrti, jak nepřímo vyplývá z Frieserova nekrologu z roku 1908 (Anonymus 1908d). Schildbachové velká systematická sbírka přešla $\mathrm{v}$ roce 1946 jako konfiskát do sbírek Národního muzea v Praze a s ní i minerály původem od Friesera (Bohatý \& Velebil 2018).

Podle katalogu sbírky Schildbachové měla její sbírka 4729 položek minerálů, z toho 1744 položek pocházelo ze sbírky J. Friesera. S ním se Schildbachová patrně osobně znala, je velmi pravděpodobné, že navštěvovala litoměřické burzy minerálů. Od Friesera získala Schildbachová výměnou ještě za jeho života 50 ukázek minerálů, například apofylity z Mariánské hory v Ústí nad Labem, zeofylity z Radejčína, gismondin z Dolních Zálezel, titanit z Proboštova, ale i 23 ukázek minerálů zahraničních.

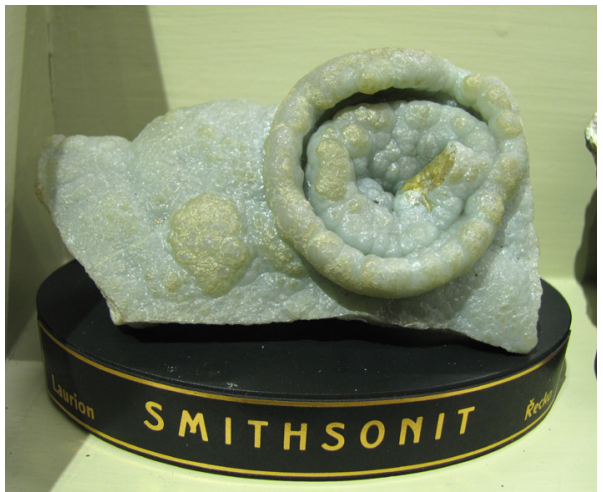

Obr. 15. Smithsonit, Laurion, Řecko, velikost vzorku $8 \times 5 \mathrm{~cm}$ (Národním muzeum P1N69919, ex coll. J. Frieser no. 858). Foto: D. Velebil. Schildbachová také nakupovala minerály od litoměřického obchodníka Leitenbergera (Bohatý, Velebil 2018).

Během částečné revize minerálů původem od Schildbachové bylo zjištěno, že minerály mají dva typy výrazně odlišných polepek s popisy. Polepky s vepsaným inventárním číslem 


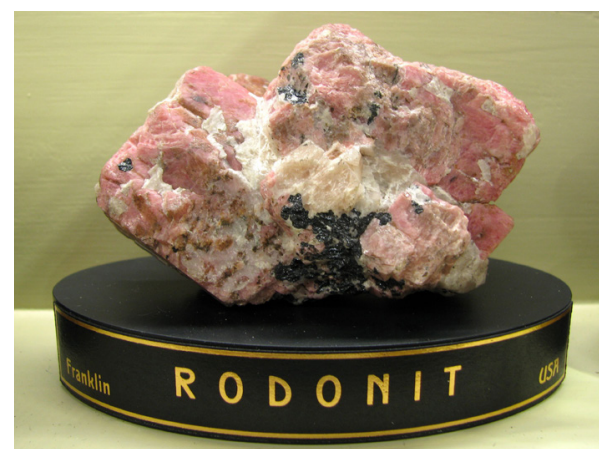

Obr. 16. Rodonit, Franklin, USA, velikost vzorku $8 \times 5 \mathrm{~cm}$ (Národní muzeum P1N71123, ex coll. J. Frieser no. 1756). Foto: D. Velebil.

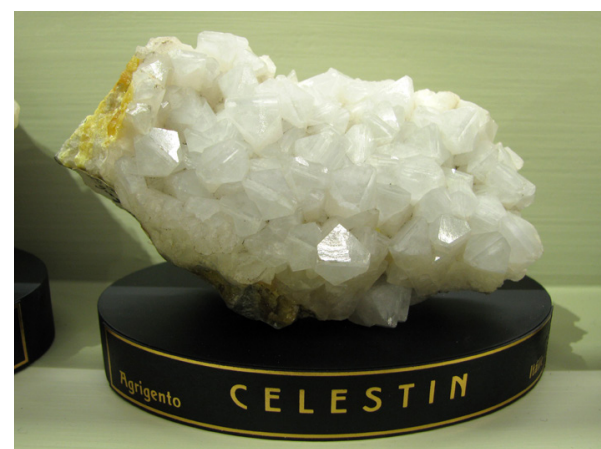

Obr. 17. Celestin, Agrigento, Itálie, velikost vzorku 9,5 ×5 cm (Národní muzeum P1N71403, ex coll. J. Frieser no. 1014). Foto: D. Velebil.

jsou na minerálech pocházejících z Frieserovy sbírky. Schildbachová vzorky nečíslovala. Velmi charakteristický rukopis Schildbachové bylo možné dobře odlišit od Frieserova porovnáním s rukopisem na jejích herbářových listech uložených v muzeu v Mariánských Lázních a s rukopisem jejího dochovaného dopisu. Původ minerálů od Friesera bylo možné ověřit i podle katalogu sbírky Schildbachové, v němž tato sběratelka u každé položky uváděla zdroj, tedy od koho kámen získala.

Následně byla provedena kompletní revize všech 2716 inventárních položek minerálů původem od Schildbachové uložených ve sbírce Národního muzea a podle nalepených štítků byly identifikovány minerály pocházející původně ze sbírky Julia Friesera. Revizí se takto podařilo identifikovat 854 minerálů z Frieserovy sbírky. Záznam o původu od Friesera byl ke každé položce připsán do elektronického inventáře mineralogické sbírky Národního muzea, včetně Frieserova původního inventárního čísla. Nejvyšší zaznamenané inventární číslo bylo 3891 (garnierit, Nová Kaledonie, Národní muzeum P1N70489), což nám dává představu o velikosti Frieserovy sbírky. Sbírka byla uspořádána systematicky, prvky mají nízká inventární čísla, silikáty nejvyšší. V souboru 854 minerálů původem od Friesera je zastoupeno celkem 344 druhů, což bude asi zhruba odpovídat i počtu druhů v celém původním Frieserově souboru. Jak Frieserova, tak sbírka Schildbachové byly systematické, tzn. že se oba snažili shromáždit co nejvíce druhů minerálů a je proto nepravděpodobné, že by Schildbachová při zařazování Frieserových minerálů do své sbírky nějaké druhy vyřazovala.

V muzejním Frieserově souboru jsou minerály z asi 40 zemí světa. Nejvíce je vzorků z Čech (254), z Moravy pouze čtyři. Dalšími hojně zastoupenými zeměmi jsou Německo (141), Rakousko (70), Norsko (55), Itálie (49), USA (43), Rumunsko (27), Řecko (27), Švýcarsko (25), Anglie (23), Francie (12), Slovensko (11), Polsko (10), Švédsko (10), Rusko (9), Kanada (9), Španělsko (8), Austrálie (8), Grónsko (6), Slovinsko (6), Chile (5), Faerské ostrovy (5), Argentina (3), Belgie (2), Bolívie (2), Brazílie (2), Finsko (2), Island (2), Mexiko (2), Skotsko (2), Japonsko (2), po jednom vzorku je z Alžířska, Bosny a Hercegoviny, Egypta, Irska, Mad’arska, Nové Kaledonie, Nového Zélandu, Srbska a Ukrajiny.

Zvláštní pozornost věnoval Julius Frieser zeolitům, jejichž výskyty jsou typické pro České středohoří, tedy region jeho terénních mineralogických sběrů. V identifikovaném souboru v Národním muzeu je například šest vzorků heulanditu z pěti zahraničních lokalit, deset chabazitů z pěti českých a čtyř zahraničních nalezišt', dále 14 natrolitů z osmi českých lokalit, 12 phillipsitů ze sedmi českých lokalit, šest stilbitů z jedné české a čtyř zahraničních nalezišt', 11 thomsonitů z devíti českých nalezišt' a šest zeofylitů z Radejčína.

Celkem sedm ukázek minerálů, původem od Friesera, je od roku 2020 vystaveno v systematické mineralogické expozici na Sále minerálů v historické budově Národního muzea na Václavském náměstí v Praze. Jsou to tyto položky: P1N69843 cerusit, Stř́ibro, Čechy 
(Frieser no. 912), P1N69919 smithsonit, Laurion, Řecko (Frieser no. 858), P1N71123 rodonit, Franklin, USA (Frieser no. 1756), P1N71403 celestin, Agrigento, Itálie (Frieser no. 1014), P1N70417 biotit, Žim, Čechy (Frieser no. 1609), P1N71471 pyromorfit, Stř́ibro, Čechy (Frieser no. 1337) a P1N71568 leadhillit, Leadhills, Skotsko (Frieser bez č.).

\section{Závěr}

Podrobnou revizí minerálů původem ze sbírky Julie Schildbachové, uložených ve sbírce Národního muzea v Praze, se podařilo identifikovat 854 položek minerálů ze sbírky známého sběratele Julia Friesera. Celá Frieserova systematická sbírka čítala původně asi necelé čtyři tisíce položek a zahrnovala asi 350 druhů minerálů pocházejících $\mathrm{z}$ nalezišst' $\mathrm{z}$ celého světa. Sběratelka Julia Schildbachová, která po Frieserově smrti jeho sbírku nebo alespoň její podstatnou část získala, z ní zařadila do sbírky své celkem 1744 položek minerálů a výrazně tak ve své sbírce navýšila počet druhů minerálů.

Pátráním po osudech a působení sběratele minerálů Julia Friesera, ale i dalších: Adalberta Wraného, Julie Schildbachové, Ludwiga Mayera či Josefa Ryše (Bohatý \&

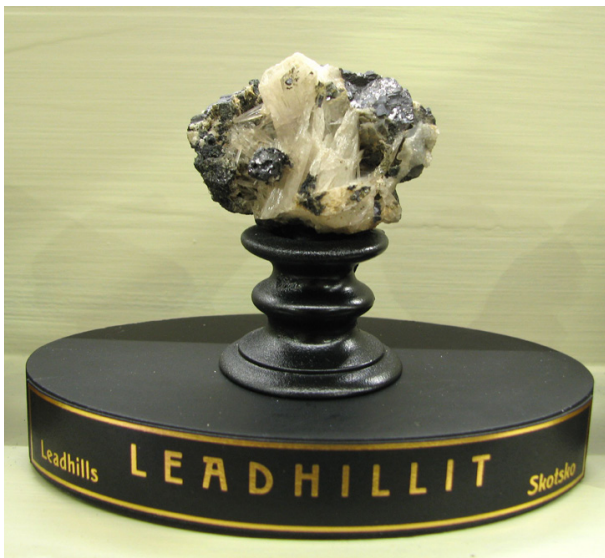

Obr. 18. Leadhillit, Leadhills, Skotsko, velikost vzorku $4 \times 3 \mathrm{~cm}$ (Národní muzeum P1N71568, ex coll. J. Frieser, bez čísla). Foto: D. Velebil. Velebil 2018, 2019; Radoň \& Velebil 2018; Ulčová \& Velebil 2020) se dozvídáme mnohé o sběratelských aktivitách těchto osobností a o společenském životě v našem regionu ve druhé polovině 19. a v první polovině 20. století. Získáváme alespoň částečný obraz toho, jak tito vyspělí amatérští mineralogové konali, veřejně působili a jak spolupracovali s profesionální vědeckou obcí. V př́ípadě Julia Friesera jsou obzvláště cenné informace o někdejším bohatém spolkovém životě v Litoměřicích a o aktivitách zdejšího klubu sběratelů minerálů, které měly přesah daleko za hranice regionu.

\section{Poděkování}

Tato práce vznikla za finanční podpory Ministerstva kultury ČR v rámci institucionálního financování dlouhodobého koncepčního rozvoje výzkumné organizace Národní muzeum DKRVO 2019-2023/15.I.c, 00023272). Poděkování patří i oběma recenzentům, jednomu anonymnímu a F. Vackovi za připomínky k rukopisu.

\section{Literatura}

Anonymus, 1872: Schwurgerichtsverhandlung. - Leitmeritzer Zeitung 2(33 - Beilage): 257-258.

Anonymus, 1874a: Fortbildungsverein „Schiller“. - Leitmeritzer Zeitung 4, $92: 759$.

Anonymus, 1874b: Fortbildungsverein „Schiller“. - Leitmeritzer Zeitung 4, 97: 802.

Anonymus, 1874c: Fortbildungsverein „Schiller“. - Leitmeritzer Zeitung 4, 98: 814.

Anonymus, 1875a: Die ordentliche Generalversammlung des Spar- und Vorschussvereines. Leitmeritzer Zeitung 5, 10: 82.

Anonymus, 1875b: Fortbildungsverein „Schiller“. - Leitmeritzer Zeitung 5, 6: 46.

Anonymus, 1875c: Damenabend. - Leitmeritzer Zeitung 5, 39: 335. 
Anonymus, 1876a: Der Spar- und Vorschussverein. - Leitmeritzer Zeitung 6, 1: 4.

Anonymus, 1876b: Der Spar- und Vorschussverein. - Leitmeritzer Zeitung 6, 83: 778.

Anonymus, 1878: Fortbildungsverein „Schiller“. - Leitmeritzer Zeitung 8, 31: 299.

Anonymus, 1881a: Ernennung. - Leitmeritzer Zeitung 11, 67: 795.

Anonymus, 1881b: Zprávy. Věstník úřednický. - Budivoj 17, 72: 2.

Anonymus, 1882: Ronsperg, 15. Juli. (Deutscher Schulverein.) - Bohemia 55, 198 - Beilage): 3. Anonymus, 1885a: Personalnachrichten. - Prager Abendblatt 1885, 133: 2.

Anonymus, 1885b: Amtliche Veröffentlichungen. Personalnachrichten. - Allgemeine österreichische Gerichts-Zeitung 36, 50: 200.

Anonymus, 1885c: Uebersetzungen im Justizdienste. - Leitmeritzer Zeitung 15, 46: 664.

Anonymus, 1893a: Personalien. - Allgemeine österreichische Gerichts-Zeitung 44, 45: 372.

Anonymus, 1893b: Ernennungen. - Gerichtshalle 37, 45: 397.

Anonymus, 1893c: Ernennungen und Versetzungen. - Zeitschrift für Notariat und freiwillige

Gerichtsbarkeit in Oesterreich 35, 45: 282.

Anonymus, 1894: Schwurgericht - Teplitz-Schönauer Anzeiger 34, 95: 6.

Anonymus, 1895: Schwurgericht - Teplitz-Schönauer Anzeiger 35, 21: 4.

Anonymus, 1899: Konkretální status úředníků a sluhů c.k. soudů a státních zastupitelstev v obvodu vrchního zemského soudu v království Českém dle stavu dne 31. prosince 1898.

- Praha: Presidium c.k. vrchního zemského soudu, 528 + XVI pp.

Anonymus, 1900: Konkretální a osobní status veškerých služebních kategorií u soudů sborových a okresních v obvodu c.k. vrchního zemského soudu v království Českém. 1899. - Praha: Presidium c.k. vrchního zemského soudu, 193 pp.

Anonymus, 1902: Notizen. Mittheilungen der Wiener Mineralogischen Gesellschaft. Tschermak's mineralogische u petrographische Mitteilungen 21, 5: 456-461.

Anonymus, 1903: Notizen. Mitteilungen der Wiener Mineralogischen Gesellschaft. Tschermak's mineralogische u petrographische Mitteilungen 22, 1: 79-88, Wien.

Anonymus, 1905: Soudcovské jmenování v království českém. - Národní listy 45, 165: 2-3.

Anonymus, 1906a: 40jähriges Dienstjubiläum. - Leitmeritzer Zeitung 36, 98: 3.

Anonymus, 1906b: 40-jähriges Dienstjubiläum. - Teplitz-Schönauer Anzeiger 46, 151 Beilage: 1-2.

Anonymus, 1906c: Leitmeritz, 20. Dez. (Jubileumsfeier). - Prager Abendblatt 1906, 291: 4.

Anonymus, 1906d: Dienstjubiläum. - Bohemia 79, 352: 7.

Anonymus, 1906e: Mitteilungen der Wiener Mineralogischen Gesellschaft. Ausstellung: Zinnstein. - Tschermaks mineralogische und petrographische Mitteilungen 25, 1-3: 232-233.

Anonymus, 1907a: Auszeichnungen. - Pilsner Tagblatt 8, 260: 2.

Anonymus, 1907b: Kaiserliche Auszeichnung. - Leitmeritzer Zeitung 37, 74: 5.

Anonymus, 1907c: Titelverleihungen. - Teplitz-Schönauer Anzeiger 47, 112: 9.

Anonymus, 1908a: Hofrat Julius Freiser gestorben. - Leitmeritzer Zeitung 38, 51: 4.

Anonymus, 1908b: Leitmeritz, 27. Juni. Sterbefall. - Teplitz-Schönauer Anzeiger 48, 77: 9.

Anonymus, 1908c: Korrespondenzen aus Böhmen. Tuschkau, 30. Juni. (Begräbnis.) - Pilsner Tagblatt 9, 181: 6-7.

Anonymus, 1908d: Hofrat Freiser †. - Leitmeritzer Zeitung 38, 52: 5.

Anonymus, 1908e: Hofrat Frieser †. - Prager Abendblatt 42, 151: 2.

Becke F., 1909: Zum Gedächtnis an Dr. Felix Cornu. - Tschermak's mineralogische u petrographische Mitteilungen 28, 5: I-IV.

Blumentritt, F., 1912: Beiträge zur Geschichte des Anpflanzungs- und VerschönerungsVereines in Leitmeritz. - Separatabdruck, Leitmeritzer Zeitung 42: 98-102.

Bohatý M. \& Velebil D., 2018: Julia Hufnagel-Schildbachová (1880-1962) - nejvýznamnější sběratelka minerálů v Čechách a její sbírka v Národním muzeu v Praze. - Journal of the National Museum (Prague), Natural History Series 187: 85-138. https://doi. org/10.2478/jnmpnhs-2018-0005 
Bohatý M. \& Velebil D., 2019: Med. Dr. Adalbert Wraný (1836-1902) - lékař, sběratel minerálů a mecenáš Národního muzea v Praze. - Journal of the National Museum (Prague), Natural History Series 188: 95-146. https://doi.org/10.2478/jnmpnhs-2019-0005

Cornu F., 1903: Zeolithvorkommen des böhmischen Mittelgebirges. Tschermak's mineralogische und petrographische Mitteilungen 22, 3/4: 373-378.

Cornu F., 1906: Zur Unterscheidung der Minerale der Glimmerzeolithgruppe. Tschermak's mineralogische und petrographische Mitteilungen 25, 6: 513-521.

Cornu F., 1911: Der Phonolith-Lakkolith des Marienberg-Steinberges bei Aussig a. d. E. Tschermak's mineralogische und petrographische Mitteilungen 30, 1/2: 1-84.

Cornu M., 1923: Lebensskizze Felix Cornus von seiner Mutter (pozn. Marie). - In: Felix Cornu. Blätter liebenden Gedenkens und Verstehens. Ein Familienbuch für den Freundeskreis; mit Widmungen namhafter Zeitgenossen, naher Freunde, und einer Lebensskizze von seiner Mutter. Nebst einer Auswahl wissenschaftlicher Arbeiten des Verewigten. 147 pp. Dresden und Leipzig: Verlag von Theodor Steinkopff.

Görgey R., 1909: Über Mesolith. - Tschermak's mineralogische u petrographische Mitteilungen 28, 1/2: 77-106.

Hibsch J. E., 1934: Die Minerale des Böhmischen Mittelgebirges. - Jena: Verlag von Gustav Fischer, $\mathrm{X}+196 \mathrm{pp}$.

Hibsch J. E., 1937: Die Minerale des Böhmischen Mittelgebirges. Ein Nachtrag. - Zeitschrift für Kristallographie, Mineralogie und Petrographie, Abteilung B, Mineralogische und petrographische Mitteilungen 49, 6: 442-458.

Nowak G., 1923: Gedenkblätter, Widmungen usw. - In: Felix Cornu. Blätter liebenden Gedenkens und Verstehens. Ein Familienbuch für den Freundeskreis; mit Widmungen namhafter Zeitgenossen, naher Freunde, und einer Lebensskizze von seiner Mutter. Nebst einer Auswahl wissenschaftlicher Arbeiten des Verewigten. 147 pp. Dresden und Leipzig: Verlag von Theodor Steinkopff.

Peiter W., 1931: Die Mineralien des Leitmeritzer Gerichtsbezirkes. - 7. Jahrbuch der „Arbeitsgemeinschaft für Heimatforschung“ in Leitmeritz: 11-12.

Radoň M., 2016: Julius Frieser - soudní úředník a sběratel minerálů. - Zprávy a studie Regionálního muzea v Teplicích 31: 77-106.

Radoň M. \& Velebil D., 2018: Ludwig Mayer, významný sběratel minerálů, a jeho sbírka v Národním muzeu v Praze. - Journal of the National Museum (Prague), Natural History Series, 187 (2018): 65-84. https://doi.org/10.2478/jnmpnhs-2018-0004

Ressel G. A., 1877: Adress-Buch des Gerichtsbezirkes Leitmeritz mit Wohnungs-Anzeiger von Leitmeritz. Zugleich historisch-topografisch-statistisches Handbuch. - Leitmeritz: 1. Auflage, 163 pp.

Seifert F, 1903: Adress-Buch des politischen Bezirkes Leitmeritz mit Wohnungs-Anzeiger der Städte Leitmeritz, Theresienstadt, Lobositz und Auscha. Im Juni 1903. - Leitmeritz: Druck und Verlag von F. Seifert und Co., 185 pp.

Ulčová H. \& Velebil D., 2020: Josef Ryš (1879-1960), pedagog, mineralog, sběratel a jeho sbírka minerálů v Národním muzeu v Praze. - Journal of the National Museum (Prague), Natural History Series 189: 31-48. https://doi.org/10.37520/jnmpnhs.2020.005

Wraný A., 1896: Die Pflege der Mineralogie in Böhmen. Ein Beitrag zur vaterländischen Geschichte der Wissenschaften. - Prag: H. Dominicus, 421 pp. 


\section{Summary}

Julius Frieser (1843-1908) was a prominent mineral collector. After graduating from Gymnasium in Pilsen, he studied law in Prague. He worked in courts in several places, including the district courts in Poběžovice and Litoměřice, where he eventually became a councilor of the Supreme Regional Court. In Litoměřice and Poběžovice, he was active in several associations, including the Schiller educational association. During meetings of the association, he lectured on geography, meteorology and meteorites. His main hobby was mineralogy. As an active and passionate collector of minerals, he was known not only in Litoměřice, but also in wider mineralogical circles. Mineralogical samples from his collections were used for research by important mineralogists in Prague and Vienna. He was a member of the Litoměřice Mineral Collectors' Club, which organized regular mineralogical exchanges around the turn of the $19^{\text {th }}$ and $20^{\text {th }}$ centuries, attended

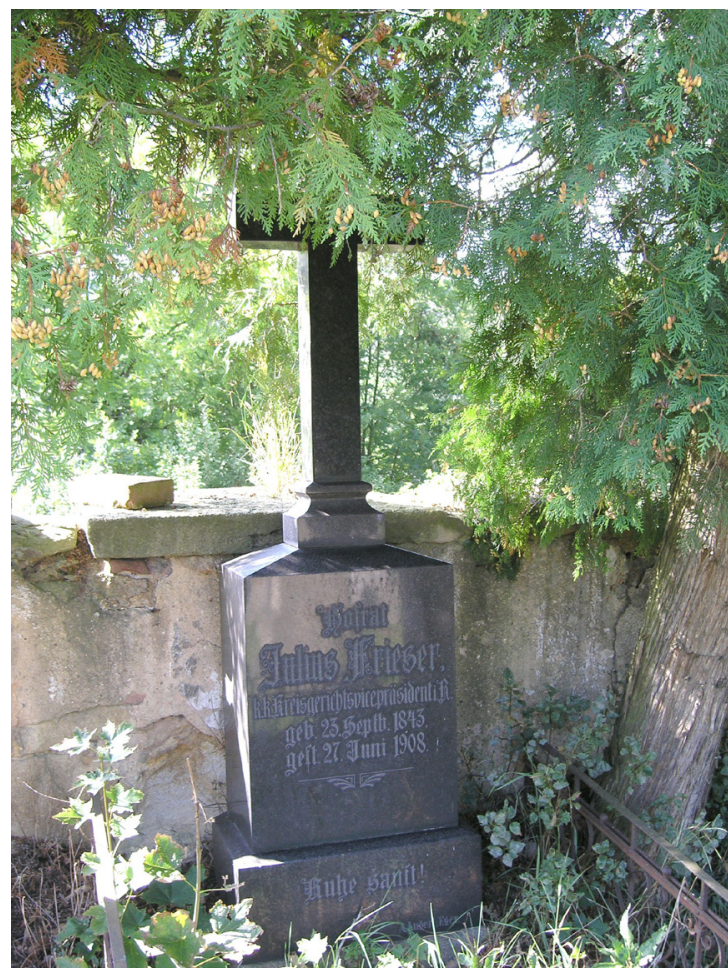

Obr. 19. Hrob Julia Friesera na hřbitově ve Městě Touškově (rok 2008). Foto: T. Smola. by collectors as well as important mineralogists and geologists from distant parts, and was also a member of the Vienna Mineralogical Society. He explored a number of mineralogical sites, especially in the vicinity of Poběžovice and in the Bohemian Central Mountains, and discovered a new locality of the mineral mesolite in Bedřichov near Benešov nad Ploučnicí. From 1896 to 1902 he was a guide and advisor to the young Felix Cornu (1882-1909), with whom he undertook joint expeditions for minerals, and who soon also became a highly respected professional mineralogist and petrographer. Julius Frieser has built an extensive systematic collection of minerals from around the world, numbering about four thousand items and about 350 species. Frieser's primary supplier was the renowned Litoměřice mineral trader Fritz Leitenberger (1857-1910), who had rich business contacts all over the world. After Frieser's death, his collection or part of it was acquired by the mineral collector Julia Schildbach from Mariánské Lázně. Her collection was acquired by the National Museum in Prague in 1946. At present, 854 items of minerals originally from Julius Frieser's mineralogical collection have been identified at the National Museum, Prague. 